\title{
An Immunological System for the Detection of Pepper mild mottle virus in Soil from Green Pepper Fields
}

\author{
Y. Ikegashira, T. Ohki, U. T. Ichiki, T. Higashi, K. Hagiwara, T. Omura, Y. Honda, and S. Tsuda, National Agri- \\ cultural Research Center, Tsukuba, Ibaraki 305-8666, Japan
}

\begin{abstract}
Ikegashira, Y., Ohki, T., Ichiki, U. T., Higashi, T., Hagiwara, K., Omura, T., Honda, Y., and Tsuda, S. 2004. An immunological system for the detection of Pepper mild mottle virus in soil from green pepper fields. Plant Dis. 88:650-656.

A reliable method, based on the double antibody sandwich enzyme-linked immunosorbent assay (DAS-ELISA), was developed for the extraction of viruses from soil and optimized for the detection of Pepper mild mottle virus (PMMoV) in soil taken from green pepper (Capsicum annuит) fields. When added to phosphate buffer, Tween 20 increases extraction efficiency and skim milk increases the specificity for PMMoV. Samples positive by DAS-ELISA were verified by inhibition testing using specific anti-PMMoV antibody, immuno-electron microscopy, reverse transcription-polymerase chain reaction, and inoculation tests on assay plants. Our system for detecting PMMoV in soil was successfully tested on samples from 22 infected and uninfected fields in Japan. When used before seedlings are planted, this method allows for the prediction of possible damage to cultivated plants by soil-borne PMMoV.
\end{abstract}

Additional keywords: methyl bromide, serology

Pepper mild mottle virus (PMMoV), which belongs to the genus Tobamovirus, is one of the most significant pathogenic causes of economic loss in green pepper (Capsicum annuum L.) production worldwide $(9,16,21)$. Like other tobamoviruses, PMMoV is transmitted through seeds and soil $(11,12,19)$. Once a green pepper field has been contaminated with the virus, decontamination is extremely difficult as long as green pepper is continuously cultivated; the virus persists stably in infected plants and infects newly transplanted seedlings. Methyl bromide is the only chemical known to effectively prevent the spread of the virus. Until now, methyl bromide has been used to fumigate soil between green pepper cultivations $(23,24)$. However, according to the Montreal Protocol, the chemical may no longer be used in developed countries beyond 2005. Consequently, alternative strategies to control $\mathrm{PMMoV}$ in green pepper fields are urgently needed.

PMMoV has a positive-strand RNA genome consisting of 6,357 nucleotides. The

Corresponding author: Shinya Tsuda

E-mail: shinyat@affrc.go.jp

Present address of first author: Katakura Chikkarin Co. Ltd., Chiyoda, Tokyo 100-0004, Japan.

Fourth and fifth authors are supported in part by Japan Science and Technology Corporation, Kawaguchi, Saitama, 332-0012 Japan.

Accepted for publication 26 January 2004.

Publication no. D-2004-0324-01R

(C) 2004 The American Phytopathological Society virus encodes at least four proteins: a 126$\mathrm{kDa}$ replicase, a $183-\mathrm{kDa}$ replicase, a movement protein, and a coat protein $(\mathrm{CP}$; 9). Infected green pepper plants produce a large viral titer. As the $\mathrm{CP}$ is expressed in infected cells at higher levels than other viral proteins, an antibody specific to $\mathrm{CP}$ is frequently used to demonstrate the presence of the virus, e.g., in diagnostic tests (21). A diagnostic kit for PMMoV based on the double antibody sandwich method of enzyme-linked immunosorbent assay (DAS-ELISA) using a CP-specific antibody has been developed and is already available in Japan (Japan Plant Protection Association, Tokyo).

The determination of the viral concentration in soil using serological or biochemical techniques is important for the prevention of soil-borne viral diseases such as PMMoV. If numerous viruses persist in the soil, they may present a threat of infection to the next cultivation. Several techniques have been developed for determining the extent of viral contamination in soil. These include infectivity assays $(5,22)$, spectrophotometry (3), and reverse transcription-polymerase chain reaction (RT-PCR) (6). These techniques require much time, cost, and space, making it difficult to assay many samples. Serological techniques such as ELISA have the potential to be much more convenient and inexpensive than existing techniques, although they do require some specialized equipment. An efficient indirect ELISA (IdELISA) method for virus detection in soil has been previously reported (18). However, unexplained nonspecific reactions have occasionally given rise to false positives in the Id-ELISA system.

We therefore compared various extraction buffer detergents and additives with the aim of efficiently and specifically detecting PMMoV in soil by DAS-ELISA. We optimized the combination of extraction buffer additives for the DAS-ELISA system and tested the ability of this system to detect PMMoV in soil from green pepper fields in Japan.

\section{MATERIALS AND METHODS}

PMMoV-infected or uninfected soils from green pepper fields in Japan. The soils for the experiments were collected from green pepper cv. New-Tosahikari fields in Ibaraki Prefecture, Japan. PMMoV-infected soil samples were taken from several points in fields where green peppers showed severe mosaic symptoms caused by PMMoV in the previous cultivation; these samples were mixed and used as a positive control. The negative control soil samples were gathered from green pepper fields that had no history of plants infected by PMMoV.

Extraction of virus from soils. Five grams of PMMoV-infected or uninfected soil samples were suspended in $20 \mathrm{ml}$ extraction buffer (see below) in plastic tubes. Suspensions were shaken for $16 \mathrm{~h}$ at room temperature. The samples were centrifuged at $1,000 \times g$ for $30 \mathrm{~min}$, and supernatants were used for DAS-ELISA.

The buffer for PMMoV extraction from soil was based on $0.05 \mathrm{M}$ phosphate buffer (PB), $\mathrm{pH} 7.0$, with a variety of detergents added to compare with their extraction efficiencies; $0.05 \%$ (vol/vol) Triton X-100 (TX-100), $0.05 \%$ ( vol/ $/ \mathrm{vol}$ ) Nonidet P-40 (NP-40), and $0.05 \%$ (vol/vol) Tween 20 (TW-20) as nonionic detergents; $0.01 \%$ (wt/vol) sodium dodecyl sulfate (SDS) as an anionic detergent; and $0.01 \%$ (wt/vol) benzethonium chloride (BC) as a cationic detergent. Several proteins were also tested for their ability to increase specific extraction efficiency and eliminate nonspecific reactions in DAS-ELISA: $1.0 \%$ (wt/vol) skim milk (SM), $1.0 \%$ (wt/vol) bovine serum albumin (BSA), $1.0 \%$ (wt/vol) casein, and $1.0 \%$ (wt/vol) egg albumin.

Various combinations of TW-20 and SM in the range of concentrations from 0.025 to $0.1 \%$ TW-20 and 1.0 to $4.0 \% \mathrm{SM}$ were then examined. TW-20 and SM were chosen because the protein and detergent comparisons described above showed that 
they provided optimal extraction efficiency and optimal suppression of nonspecific reactions.

To increase the efficiency of PMMoV extraction from soil, the effects of altering both temperature and shaking time were examined. We performed extractions at room temperature $\left(25^{\circ} \mathrm{C}\right)$ or at $70^{\circ} \mathrm{C}$ and shook the soil suspensions for $2 \mathrm{~min}, 30$ min, or $1,2,4,8,16$, or $24 \mathrm{~h}$.

DAS-ELISA. Throughout the experiment, a purified PMMoV solution (Japanese strain; 9) at a final concentration of $0.5 \mu \mathrm{g} / \mathrm{ml}$ was used as a standardized positive control for DAS-ELISA. Our DASELISA system was based on the method described by Clark and Adams (4) with some modifications, using a specific antibody to PMMoV (21). Antibody-coated plates were washed three times with 0.05 $\mathrm{M}$ phosphate-buffered saline ( $\mathrm{pH}$ 7.4) containing $\quad 0.05 \% \quad(\mathrm{vol} / \mathrm{vol}) \quad \mathrm{TW}-20$ (PBST); plates were then incubated for 2 $\mathrm{h}$ at $37^{\circ} \mathrm{C}$ with $\mathrm{PB}(\mathrm{pH} 7.0)$ containing $2.0 \%$ (wt/vol) SM and $0.05 \%$ (wt/vol) sodium azide. Extracted soil samples were put into the wells of the plates and incubated for $2 \mathrm{~h}$ at $37^{\circ} \mathrm{C}$. Alkaline phosphatase-conjugated PMMoV antibody, diluted 2,000 times in PBST, was added to plates to detect the virus. After $2 \mathrm{~h}$ incubation, plates were washed with PBST; then substrate $\quad(1.0 \quad \mathrm{mg} / \mathrm{ml} \quad p$-nitrophenylphosphate in $10 \%$ [vol/vol] diethanolamine, adjusted to $\mathrm{pH} 9.8$ with $\mathrm{HCl}$ ) was added. After incubation for $1 \mathrm{~h}$ at $25^{\circ} \mathrm{C}$, absorbance at $405 \mathrm{~nm}\left(A_{405}\right)$ was determined using an ELISA plate reader (Model 550, Bio-Rad, Hercules, CA). The reader was auto-zeroed using a sample-free well, but substrate-contained, to make a baseline.

Inhibition test of extracted solution from soils. An inhibition test was performed by adding PMMoV-antibody (10 $\mu \mathrm{g} / \mathrm{ml}$ ) to extracted samples (antibody treatment). A solution of BSA $(10 \mu \mathrm{g} / \mathrm{ml})$ instead of the antibody was employed as a negative control (BSA treatment). After $2 \mathrm{~h}$ incubation at $37^{\circ} \mathrm{C}$, the samples were centrifuged at $20,600 \times g$ for $5 \mathrm{~min}$ at $4^{\circ} \mathrm{C}$. Supernatants were subjected to DASELISA as described above. ELISA absorbances for the two solutions, antibody and BSA treatment, were compared to determine the extent of nonspecific reactions and thereby the absorbance genuinely due to the virus.
Confirmation of positive reaction to PMMoV in DAS-ELISA. To determine whether positive reactions in DAS-ELISA were really caused by $\mathrm{PMMoV}$, three experiments were conducted using extracts from infected soil. First, immunoelectron microscopy was performed according to the method of Lin (13). After treatment with the primary antibody to PMMoV, which is the same as the one used for ELISA, anti-rabbit immunoglobulin G coupled to 10 -nm gold particles (British Biocell International, Cardiff, UK) was added. Samples were negatively stained with $2.0 \%$ (wt/vol) uranyl acetate and observed under a Hitachi H-7000 electron microscope to observe the reaction of the virus with antiPMMoV antibody.

Second, RT-PCR was used to demonstrate the presence of PMMoV RNA in extracted samples. Forward and reverse primers (both 20-mers) were designed to detect a 1.1-kbp DNA sequence from nucleotides 5,031 to 6,170 of the viral genome sequence (DDBJ accession no. AB000709). Total RNA was isolated from soil using an Inhibit EX tablet packaged in the QIAamp DNA Stool Mini Kit and the

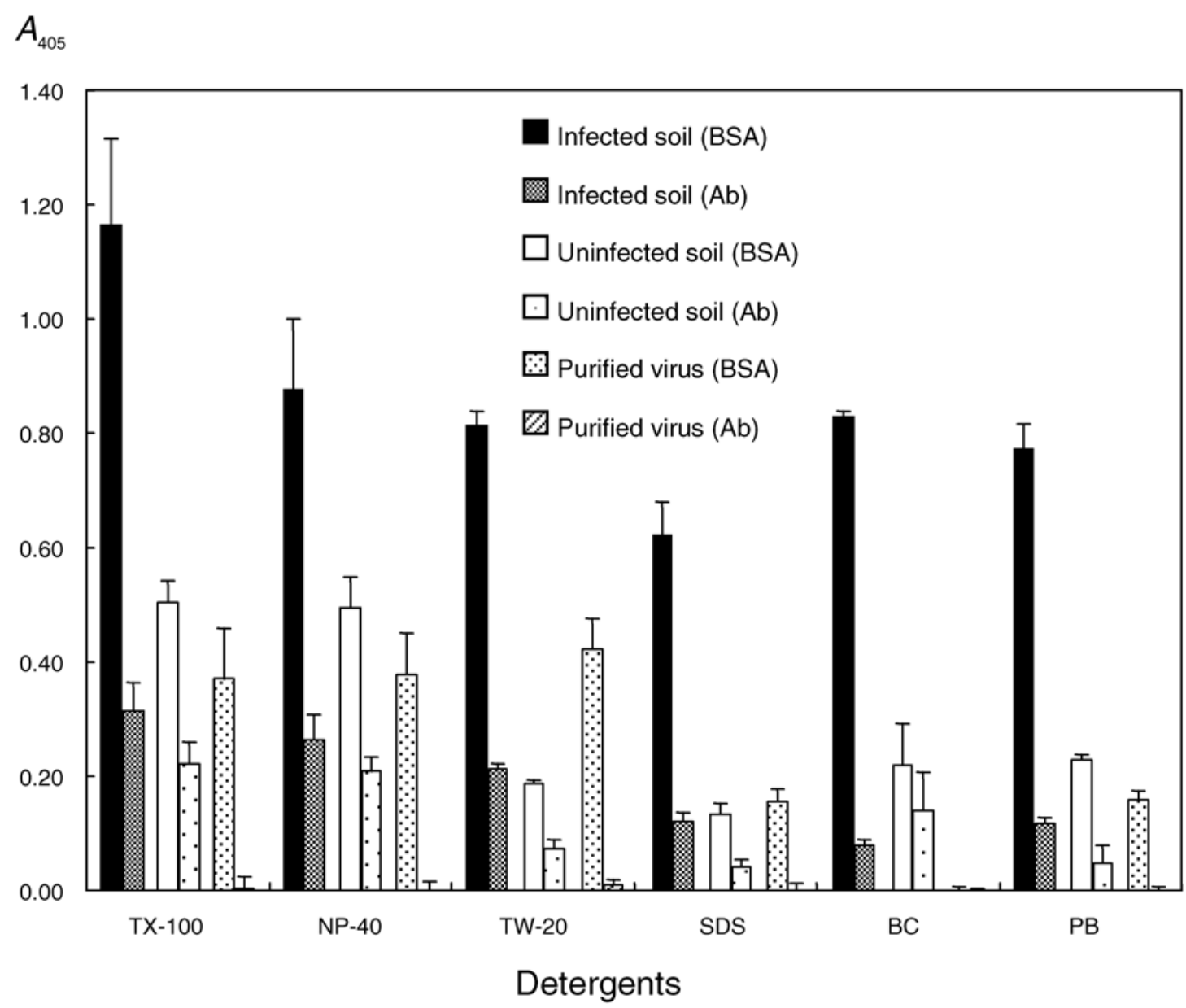

Fig. 1. Comparison of Pepper mild mottle virus (PMMoV) extraction efficiencies using five different detergents in phosphate buffer (PB) for double antibody sandwich enzyme-linked immunosorbent assay (DAS-ELISA) and inhibition tests with anti-PMMoV antibody. Infected soil, uninfected soil, and positive control (purified PMMoV; $0.5 \mu \mathrm{g} / \mathrm{ml}$ ) were assayed after treatment with either $10 \mu \mathrm{g} / \mathrm{ml}$ bovine serum albumin (BSA) or $10 \mu \mathrm{g} / \mathrm{ml}$ anti-PMMoV antibody (Ab). PMMoV was extracted from soils with PB containing Triton X-100 (TX-100), Nonidet P-40 (NP-40), Tween 20 (TW-20), sodium dodecyl sulfate (SDS), or benzethonium chloride (BC), as described in the text. Absorbance values at $A_{405}$ represent the mean of three wells. 
RNeasy Plant Mini Kit (QIAGEN, Tokyo, Japan) according to the manufacturer's instructions. RT-PCR was performed using the One Step RT-PCR Kit (QIAGEN).

Third, Nicotiana tabacum cv. Xanthi nc plants were inoculated with extracted samples and monitored for necrotic lesion development. Three milliliter extracts were ultracentrifuged at $100,000 \times g$ for $45 \mathrm{~min}$. The precipitate was suspended in $10 \mu \mathrm{l}$ of $0.05 \mathrm{M}$ PB resulting in a 300 -fold increase in concentration following rubbing of whole solution on a tobacco leaf.

Trial of DAS-ELISA on soil samples derived from green pepper fields. The DAS-ELISA system for soil was tested for its ability to detect PMMoV in soils from actual pepper fields. Twenty-two fields were randomly selected from pepper cultivation fields in the Ibaraki Prefecture, Japan. The sample included fields that had been infected in a previous cultivation and fields that had not been previously infected. One soil sample was collected per field, from a depth of 5 to $10 \mathrm{~cm}$ and at a location between plants in the central part of a greenhouse in each field. The results of DAS-ELISA were correlated with the appearance, symptomatic or asymptomatic, of pepper plants from a previous cultivation.

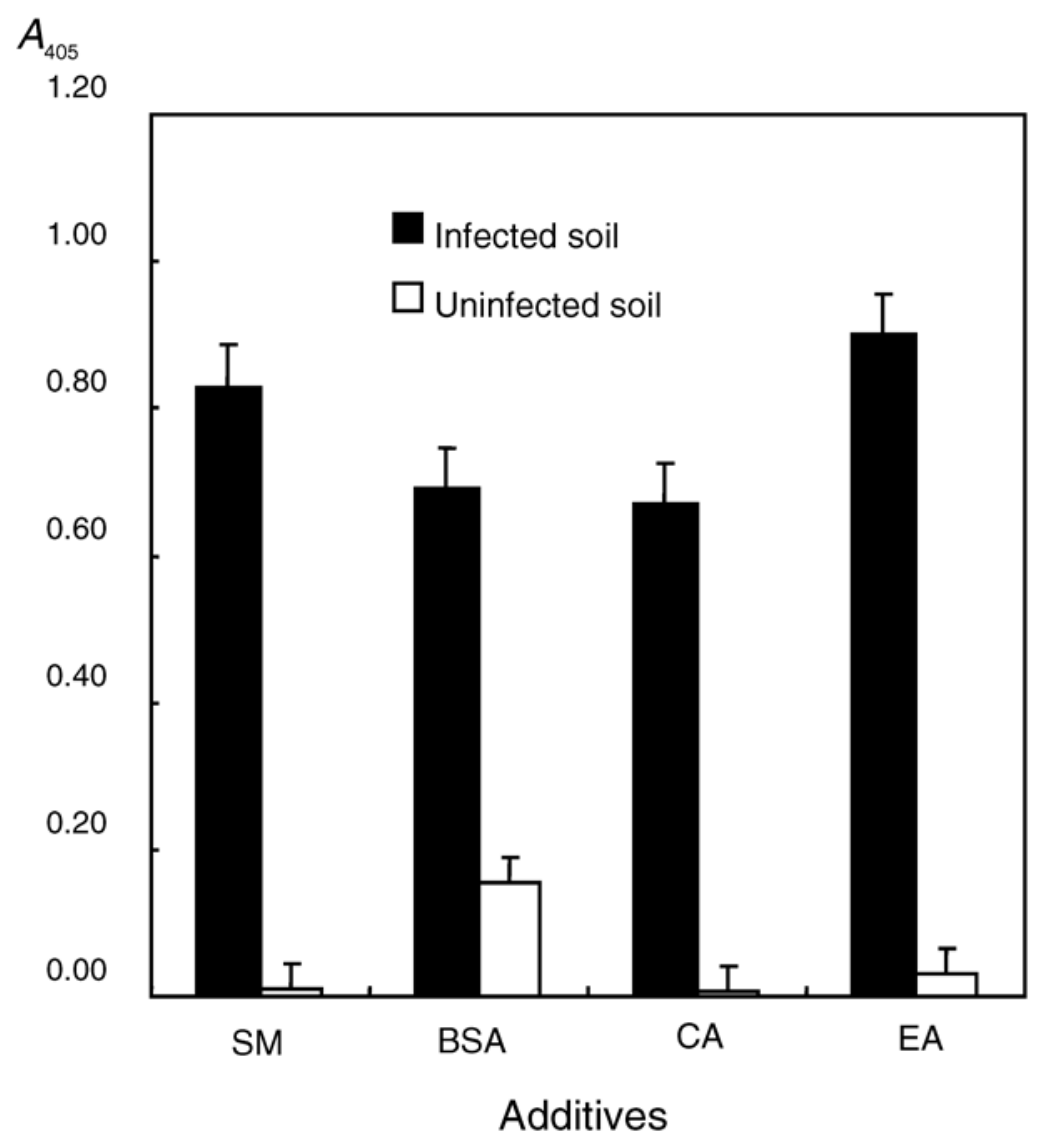

Fig. 2. Comparison of suppression of nonspecific reactions in double antibody sandwich enzymelinked immunosorbent assay (DAS-ELISA) using four different proteins in phosphate extraction buffer (PB). Infected and uninfected soils were assayed. Each soil was shaken with PB containing skim milk (SM), bovine serum albumin (BSA), casein (CA), or egg albumin (EA) to extract Pepper mild mottle virus (PMMoV) for DAS-ELISA as described in the text. Absorbance values at $A_{405}$ represent the mean of three wells. but the assay using this buffer could not detect purified virus due to interference with the antibody-antigen reaction, since the detergent is cationic. From the above results, we chose buffer containing TW-20 for extracting the virus from soils.

Comparison of nonspecific reactions using four different proteins in extraction buffer. Extraction buffers containing various proteins were compared to assess their ability to eliminate nonspecific DASELISA reactions. The results are shown in Figure 2. The extraction buffer containing egg albumin gave the highest absorbance in DAS-ELISA of infected soil; the reaction to uninfected soil was much weaker. However, egg albumin is a difficult reagent to use because it forms lumps and does not readily dissolve in $\mathrm{PB}$. Among the proteins tested, SM produced the second-highest absorbance from infected soil. The buffer containing SM displayed a significant contrast between infected and uninfected soils. Buffer containing BSA gave a lower reading for infected soil and a relatively high absorbance for uninfected soil, suggesting that this buffer may induce unexpected nonspecific reactions. Buffer containing casein produced a similar reading to BSA from infected soil, although it also gave the lowest absorbance from nonspecific reactions. SM was therefore selected from the four different proteins for specific extraction of PMMoV from soil.

Combinations of TW-20 and SM in buffer. Various combinations of TW-20 and SM were tested to optimize the extraction buffer for PMMoV from soil (Fig. 3). Among buffers containing several different quantities of both TW-20 and SM in PB, a buffer containing $0.05 \%$ (vol/vol) TW-20 and $2.0 \%(\mathrm{wt} / \mathrm{vol}) \mathrm{SM}$ showed the highest efficiency of PMMoV extraction from infected soil (open arrow). All the buffers tested produced approximately equal absorbances from purified virus. Since absorbance values for uninfected soil in all the TW-20/SM buffers were low, a buffer containing both TW-20 and SM is able to suppress nonspecific reactions with unknown soil-derived substances. Based on the results shown in Figure 3, we used PB containing $0.05 \%$ (vol/vol) TW-20 and $2.0 \%(\mathrm{wt} / \mathrm{vol}) \mathrm{SM}$ as the extraction buffer (EB) for PMMoV in soil in subsequent experiments.

Extraction conditions for PMMoV from infected soils using EB. To increase extraction efficiency using EB, two temperatures were compared: room temperature $\left(25^{\circ} \mathrm{C}\right)$ and high temperature $\left(70^{\circ} \mathrm{C}\right)$. At $25^{\circ} \mathrm{C}$, viruses were detected in DASELISA from infected soil and purified virus. The specificity was good: uninfected soil gave a very low reading (Fig. 4). At $70^{\circ} \mathrm{C}$, efficiencies for virus extraction from infected soil and purified virus were less than at $25^{\circ} \mathrm{C}$. Moreover, there was a significant nonspecific reaction to uninfected soil at $70^{\circ} \mathrm{C}$. From these results, the tem- 
perature for virus extraction from soils was fixed $25^{\circ} \mathrm{C}$.

Next, the length of the extraction step was optimized. When EB was mixed with infected soil in a tube, detectable amounts of PMMoV could be extracted in $2 \mathrm{~min}$ (Fig. 5). The quantity of extracted PMMoV increased quickly until $2 \mathrm{~h}$, to go over $70 \%$ or more of viruses, then began to plateau. No nonspecific reaction to uninfected soil was observed even after $24 \mathrm{~h}$.

Evidence that the positive reaction in DAS-ELISA is caused by PMMoV. Immuno-electron microscopy detected PMMoV particles in solutions extracted with EB (Fig. 6A). The rod-shaped virus particles appeared identical to Tobamovirus, which might be fragmented over extraction. A PMMoV-specific antibody clearly showed viral antigen on the particles (arrows). Second, RT-PCR of infected soil amplified a PMMoV-specific cDNA band with the expected length of about 1.1 kbp. RT-PCR of extracts from uninfected soil did not amplify any cDNA (Fig. 6B). Third, numerous local necrotic lesions appeared on leaves of $N$. tabacum cv. Xanthi nc 3 days after inoculation with a sam-

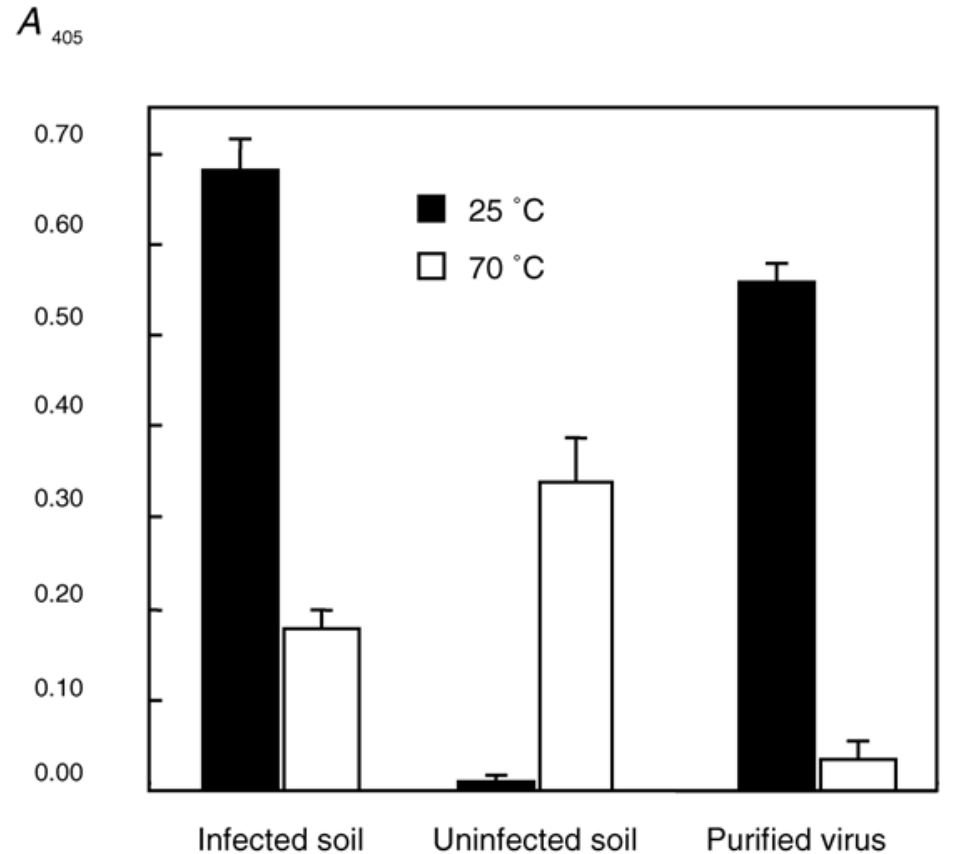

Fig. 4. Effect of temperature on Pepper mild mottle virus (PMMoV) extraction from soils. Infected soil, uninfected soil, and positive control (purified PMMoV; $0.5 \mu \mathrm{g} / \mathrm{ml}$ ) were assayed using extraction buffer $(\mathrm{EB})$ with reciprocal shaking at room temperature $\left(25^{\circ} \mathrm{C}\right)$ or high temperature $\left(70^{\circ} \mathrm{C}\right)$ for $16 \mathrm{~h}$. Absorbance values at $A_{405}$ represent the mean of three wells.

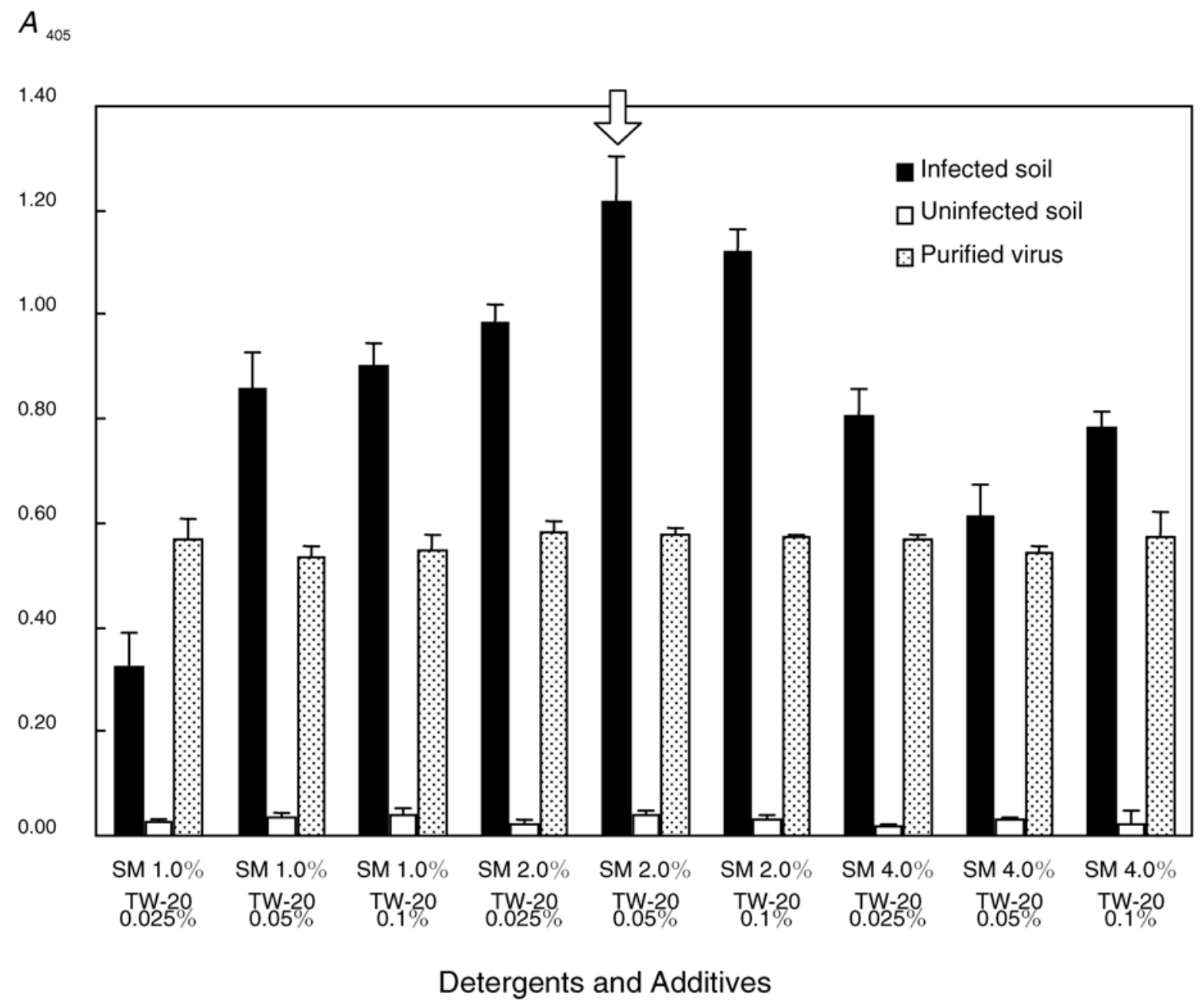

Fig. 3. Pepper mild mottle virus (PMMoV) extraction efficiencies with various concentrations of skim milk (SM) and Tween 20 (TW-20) in phosphate buffer (PB) in double antibody sandwich enzyme-linked immunosorbent assay (DAS-ELISA). Infected soil, uninfected soil, and positive control (purified PMMoV; $0.5 \mu \mathrm{g} / \mathrm{ml}$ ) were assayed. Absorbance values at $A_{405}$ represent the mean of three wells. 
ple solution extracted from infected soil with EB. An extract from uninfected soil did not cause any necrotic lesions (data not shown).

These experiments clearly demonstrate that PMMoV was specifically extracted from infected soil of green pepper fields with EB. Furthermore, the procedure could successfully extract infective virus.

Application of DAS-ELISA to soil diagnosis of PMMoV for green pepper cultivation fields. The EB described above was used to extract PMMoV from soils collected from 22 pepper cultivation fields. The sample included fields that had been infected by PMMoV in a previous cultiva- tion and fields that had not been previously infected. As shown in Figure 7, samples extracted from soils growing peppers that exhibited viral symptoms gave significant absorbances in DAS-ELISA, while those from soils growing symptomless peppers gave lower readings. A threshold line may be drawn at an $A_{405}$ of 0.1 , since the affected group was clearly separated from the symptomless group by that line. Hence, DAS-ELISA after soil extraction with EB is demonstrably useful for diagnostic PMMoV detection in soil, since ELISA values greater than 0.1 in the tests corresponded with the appearance of symptoms on pepper plants.

\section{$A_{405}$}

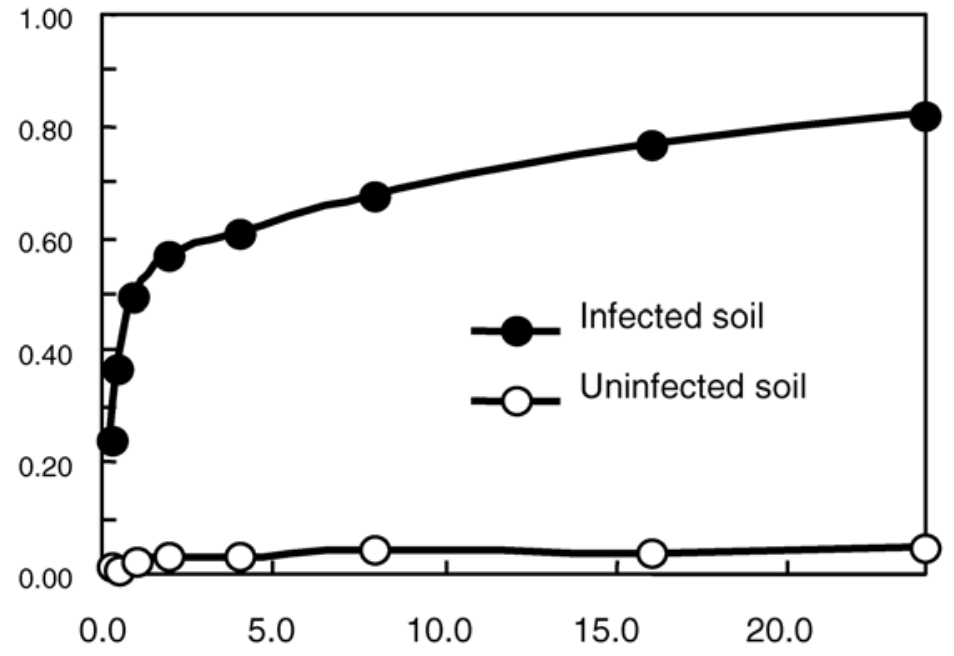

Hours

Fig. 5. Time course for recovery of Pepper mild mottle virus (PMMoV) from infected soils. Time courses for infected and uninfected soils were compared. Sampling times were $2 \mathrm{~min}, 30 \mathrm{~min}$, and 1, $2,4,8,16$, and $24 \mathrm{~h}$. Absorbance values at $A_{405}$ represent the mean of three wells.

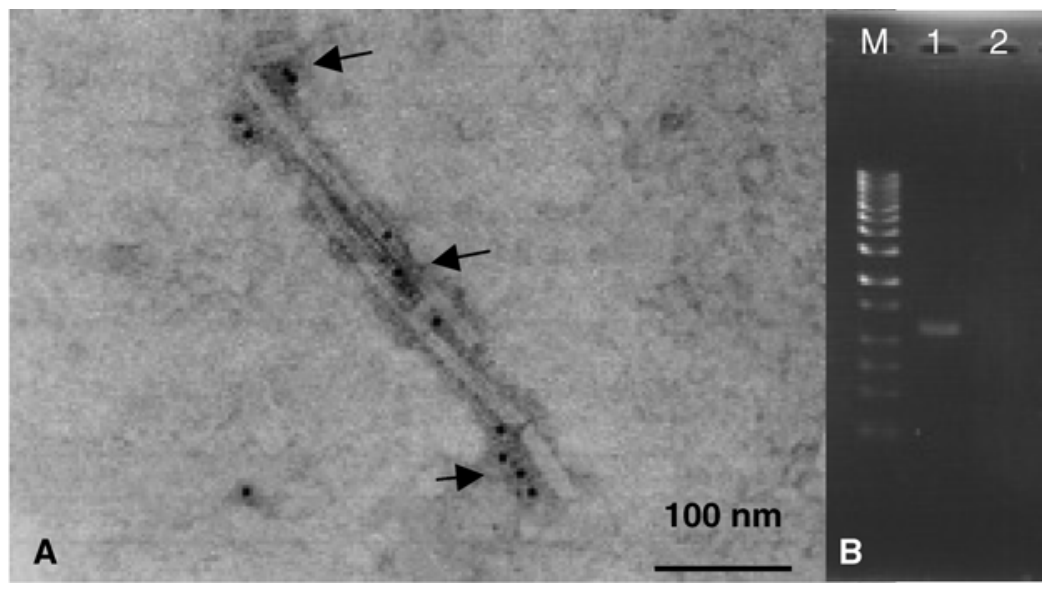

Fig. 6. Demonstrations that positive reactions in double antibody sandwich enzyme-linked immunosorbent assay (DAS-ELISA) are caused by Pepper mild mottle virus (PMMoV). Tobamovirus particles extracted from infected soil were observed by immuno-electron microscopy following antiPMMoV antibody treatment with gold (arrows in A). A cDNA band of the expected length $(1.1 \mathrm{kbp})$ is detected by reverse transcription-polymerase chain reaction (RT-PCR) only in the sample extracted from infected soil (B); infected soil (1), uninfected soil (2), molecular marker (M).

\section{DISCUSSION}

We have successfully researched an extraction buffer that can be used in DASELISA to efficiently detect PMMoV in soil. We used an inhibition test to develop a system without nonspecific reactions. Using immuno-electron microscopy, RTPCR, and an infectivity assay, we have shown that our procedure extracts infectious soil-borne virus. The DAS-ELISA system developed in the present study is applicable to the detection of PMMoV in soil from real green pepper fields.

ELISA is an established serology-based method for the detection of viruses. It is popular because of its sensitivity and the ease with which it can be used to analyze many samples. This technique has been used worldwide as a powerful diagnostic tool to detect causal viruses from infected plants and/or insect vectors for plant viruses. Unfortunately, it has been difficult to adapt ELISA to detect viruses in soils from cultivated fields, since unknown nonspecific factors have caused color development in the substrate, even when uninfected samples were used. Factors influencing the appearance of false positives could include soil $\mathrm{pH}$, moisture content, ionic concentration, cation-exchange capacity, type and amount of clay, organic matter concentration, proteins, groundwater, and isoelectric point $(1,2,17)$. False positives appeared in our experiments when soils from green pepper fields were extracted with simple PB (data not shown). There has been no previous work on elimi-

$A_{405}$

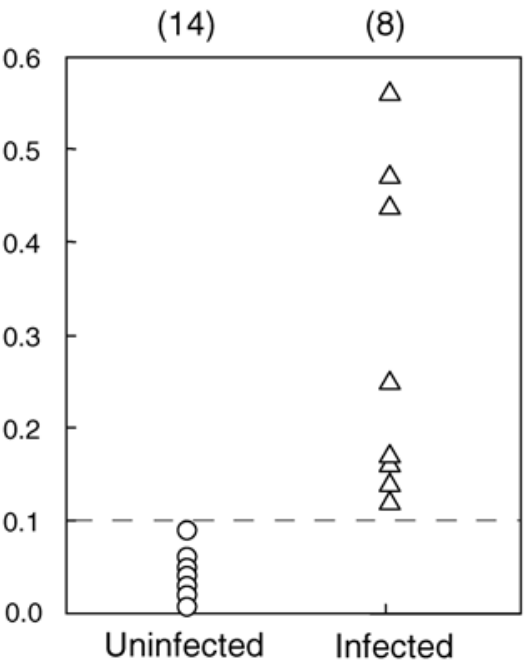

Fig. 7. Relationships between absorbance values for soils in double antibody sandwich enzyme-linked immunosorbent assay (DASELISA) and appearance of symptoms on green pepper plants in a previous cultivation. One soil sample was collected from each of 22 fields. Numbers in parentheses show the number of fields where infected (open triangle) or uninfected soil (open circle) was collected. Absorbance values at $A_{405}$ represent the mean of three wells. 
nating false positives by using particular chemicals as additives in an extraction buffer.

It is generally accepted that the addition of detergents to some buffer could increase the efficiency of extraction, since detergents have both hydrophilic and hydrophobic ends. However, detergents might be expected to resolve targets, or extract not only targets but also substances giving nonspecific reactions, especially if the detergents are of high ionic strength (17). Buffers containing either SDS or BC did indeed demonstrate this phenomenon in the present study, as shown in Figure 1. TW-20 was expected to increase extraction efficiency for viruses while avoiding nonspecific effects as far as possible, since it is one of the nonionic detergents tested. Following tests, it was chosen as an additive to extraction buffer for DAS-ELISA.

$\mathrm{SM}$ is known to be useful in preventing nonspecific reactions in ELISA systems and fully extended to use in serological experiments. In the present study, a buffer containing SM was shown to produce results consistent with the infection history of the sample fields. This result suggests that various milk proteins including SM may also have a potential for specific extraction of protein, like an effect by ion exchange (10), over extraction procedure, reducing nonspecific reactions due to unknown factors extracted from soils in ELISA. Consequently, we decided to use two reagents in $\mathrm{PB}$ as the EB: TW-20 to increase extraction efficiency and SM to enhance specific extraction of virus, according to the results shown in Figure 3.

Heat treatment at $70^{\circ} \mathrm{C}$ has been used in a previous study to increase extraction efficiency for soil viruses and was effective for detection of virus in soils by Id-ELISA (18). However, in the present study, nonspecific reactions appeared in uninfected soil with $70^{\circ} \mathrm{C}$ treatment, and the sensitivities of virus detection in supernatants from both infected soil and purified virus were decreased. One of the reasons for the decrease in sensitivity could be inactivation of viral antigenicity in positive samples by heat treatment. The reason for the increase in nonspecific reactions with uninfected soil is not clear. Nonviral material giving positive ELISA readings might be extracted even from soils with low PMMoV concentration or no virus, since it is well known that heating during extraction causes a general increase in extraction efficiency for soluble substances from soil.

Our experiments on extraction time suggest that a 2-h extraction is sufficient, since $70 \%$ or more of viruses were extracted in that period at room temperature (Fig. 5). A 2-h extraction enables the whole diagnostic procedure to be completed in one day. Overnight extraction for $16 \mathrm{~h}$ would be useful to obtain unequivocal results; using the protocol described in this study, experiments including a 16-h extraction could be completed in 2 days. Furthermore, the fact that nonspecific reactions with uninfected soils did not increase during long extractions allows the detection procedure to be started at any time of day, at the experimenter's convenience.

Inhibition testing with specific antibody is an established procedure to ensure that antibodies are detecting real antigens in serological assays $(7,8,14,20)$. In this study, the use of an IgG to PMMoV has demonstrated a significant degree of nonspecific reaction in DAS-ELISA. However, inhibition testing also demonstrated that the principle species giving a positive reaction in DAS-ELISA was PMMoV. This was further confirmed by RT-PCR, immuno-electron microscopy, and a biological assay using tobamovirus-resistant tobacco plants inoculated with samples extracted from PMMoV-infected soils as described above. These results demonstrate that intact PMMoV particles remain in soil after pepper cultivation and retain biological activity.

Id-ELISA might often be used to detect causal viruses in soils, sacrificing the greater sensitivity of DAS-ELISA, because Id-ELISA is easier to use (18). However, it has an intrinsic tendency to exhibit more nonspecific reactions than DAS-ELISA, probably because nonspecific factors can bind to the polystyrene in the initial coating in Id-ELISA. Furthermore, it seems that virus detection by Id-ELISA might be influenced by soil type. For example, the Id-ELISA previously described (18) could not detect viruses in solutions extracted from infected soils containing high concentrations of andosols, because andosols may absorb large quantities of TMV particles on the surface of amorphous clay (15), resulting in poor virus extraction. In our preliminary results, DAS-ELISA with EB has shown to be adaptable to any soil type, including andosols (data not shown). Consequently, DAS-ELISA with EB would be useful to detect soil-borne viruses such $\mathrm{PMMoV}$ in soils from actual cultivation fields, providing higher detection sensitivity and fewer nonspecific reactions than IdELISA.

Obviously, it is very difficult to control soil-borne diseases because the causal pathogens are underground. Once signs of infection by pathogens appear on plants in fields, the spread of disease rarely can be prevented without economic loss. The use of methyl bromide, currently the most effective chemical pesticide for the prevention of soil-borne disease, will be terminated in developed countries by 2005 due to the Montreal Protocol. Unfortunately, there are as yet no effective alternatives to methyl bromide. It is very important to know before pepper seedlings are planted how much damage is likely to be caused to the next cultivation by soil-borne PMMoV. Such a prediction can be made using DASELISA with the extraction buffer devel- oped in the study. This method can reveal the degree of contamination of fields by PMMoV. Such data can indicate which PMMoV-resistant pepper cultivars, such as those carrying the $L^{3}$ or $L^{4}$ gene, or other crops, should be planted to prevent an outbreak of PMMoV disease.

\section{ACKNOWLEDGMENTS}

We thank I. Fujisawa, National Agricultural Research Center, for helpful suggestions and discussions.

\section{LITERATURE CITED}

1. Abbaszadegan, M., Huber, M. S., Gerba, C. P., and Pepper, I. L. 1993. Detection of enteroviruses in groundwater with the polymerase chain reaction. Appl. Environ. Microbiol. 59:1318-1324.

2. Allen, W. R. 1984. Mode of inactivation of TMV in soil under dehydrating conditions. Can. J. Plant Pathol. 6:9-16.

3. Cheo, P. C. 1980. Antiviral factors in soil. Soil Sci. Soc. Am. J. 44:62-67.

4. Clark, M. F., and Adams, A. N. 1977. Characteristics of the microplate method of enzymelinked immunosorbent assay for the detection of plant viruses. J. Gen. Virol. 34:475-483.

5. Hurst, C. J., and Gerba, C. P. 1979. Development of a quantitative method for the detection of enteroviruses in soil. Appl. Environ. Microbiol. 37:626-632.

6. Jacobi, V., Bachand, G. D., Hamelin, R. C., and Castello, J. D. 1998. Development of a multiplex immunocapture RT-PCR assay for detection and differentiation of tomato and tobacco mosaic tobamoviruses. J. Virol. Methods 74:167-178.

7. Jiménez-Clavero, M. A., González-Rubio, C., Fontán, G., and Lopez-Trascasa, M. 1994. Factor $\mathrm{J}$, an inhibitor of the complement classical pathway: The quantitation by an ELISA inhibition assay in normal human serum. Clin. Biochem. 27:169-176.

8. Kawano, K., and Minamishima, Y. 1987. Removal of nonspecific hemagglutination inhibitors, immunoglobulin $\mathrm{G}$, immunoglobulin A with streptococcal cells and its application to the rubella hemagglutination inhibition test. Arch. Virol. 95:41-52.

9. Kirita, M., Akutsu, K., Watanabe, Y., and Tsuda, S. 1997. Nucleotide sequence of the Japanese isolate of pepper mild mottle tobamovirus (TMV-P) RNA. Ann. Phytopathol. Soc. Jpn. 63:373-376.

10. Klostermeyer, H. 1993. Relationships between ionic environment and functional behaviour of milk proteins. Pages 40-51 in: International Dairy Federation Special Issue. International Dairy Federation, Brussels, Belgium.

11. Komuro, Y., and Iwaki, M. 1969. Presence of tobacco mosaic virus in roots of field-grown tomato plants healthy in appearance. Ann. Phytopathol. Soc. Jpn. 35:294-298.

12. Lanter, J. M., McGuire, J. M., and Goode, M. J. 1982. Persistence of tomato mosaic virus in tomato debris and soil under field conditions. Plant Dis. 66:552-555.

13. Lin, N. S. 1984. Gold-IgG complexes improve the detection and identification of viruses in leaf dip preparations. J. Virol. Methods 8:181-190.

14. March, R. E., Winrow, V. R., and Holborow, E J. 1986. The specificity of human autoantibodies to IgG: The development of methodology for measuring the specificity of antiglobulin isotypes in rheumatoid and normal sera. Rheumatol. Int. 6:155-160.

15. Okabe, I., and Toriyama, S. 1995. Scanning electron microscopic observations of tobacco mosaic virus adhering to soil particles. Ann. Phytopathol. Soc. Jpn. 61:44-48.

16. Pares, R. D., and Gunn, L. V. 1989. The role of 
unvectored soil transmission as a primary source of infection by pepper mild mottle and cucumber mosaic viruses in glasshouse-grown capsicum in Australia. J. Phytopathol. 126:353-360.

17. Semith, E. 1987. Investigation on the stability of tobacco mosaic virus in soil. J. Turk. Phytopathol. 16:119-130.

18. Takeuchi, S., Hikichi, Y., Kawada, Y., and Okuno, T. 2000. Detection of Tobamoviruses from soils by unprecoated indirect ELISA. J. Gen. Plant Pathol. 66:153-158.

19. Tan, S. H., Nishiguchi, M., Sakamoto, W., Ogura, Y., Murata, M., Ugaki, M., Tomiyama, M., and Motoyoshi, F. 1997. Molecular analy- sis of the genome of an attenuated strain of cucumber green mottle mosaic virus. Ann. Phytopathol. Soc. Jpn. 63:470-474.

20. Thomas, C. B., Jasper, D. E., Boothby, J. T., and Dellinger, J. D. 1987. Enzyme-linked immunosorbent assay for detection of $M y$ coplasma californicum-specific antibody in bovine serum: Optimization of assay determinants and control of serologic cross-reactions. Am. J. Vet. Res. 48:590-595.

21. Tsuda, S., Kirita, M., and Watanabe, Y. 1998. Characterization of a pepper mild mottle tobamovirus strain capable of overcoming the $L^{3}$ gene-mediated resistance, distinct from the resistance-breaking Italian isolate. Mol. Plant-
Microbe Interact. 11:327-331.

22. Wait, D. A., and Sobsey, M. D. 1983. Method for recovery of enteric viruses from estuarine sediments with chaotrophic agents. Appl. Environ. Microbiol. 46:379-385.

23. Yoneyama, S. 1988. Control of $\mathrm{P}$ strain of tobacco mosaic virus in sweet pepper. (2) Effects of soil fumigation with methyl bromide in spring season. (in Japanese) Proc. Kanto Plant Prot. 35:53-55.

24. Yoneyama, S. 1988. Control of $\mathrm{P}$ strain of tobacco mosaic virus in sweet pepper. (3) Effects of soil fumigation with methyl bromide in summer season. (in Japanese) Proc. Kanto Plant Prot. 35:56-57. 